\title{
POPULATION DYNAMICS AND GILLNETS SELECTIVITY OF Chrysichthys nigrodigitatus (Lalepede 1803) IN LOWER REACHES OF THE CROSS RIVER ESTUARY, NIGERIA. Ajang, R. 0., ${ }^{1}$ Ndome, C. B., ${ }^{2}$ Ekwu, A., ${ }^{3}$ Uttah, E.C., ${ }^{1}$ and Iboh, C. I. ${ }^{1}$ \\ http://dx.doi.org/10.4314/ejesm.v6i1.4
}

Received 6th October 2012; accepted 10th January 2013

\begin{abstract}
Population Dynamics and gillnet selectivity of Chrysichthys nigrodigitatus (Lalepede 1803) in the lower reaches of the Cross River estuary of Nigeria was studied for two years (January 2008 - December 2009), with respect to selectivity, gillnet sizes and population of the species based on length frequency analysis. Estimates of growth parameters, asymptotic length $(L \infty)=98.25 \mathrm{~cm}$ and growth constant $(K /$ year $)=$ $0.96 \mathrm{yr}-1$. Total mortality rate $(Z)$ was $6.27 \mathrm{yr}-1$, natural mortality $(M)=1.22 \mathrm{yr}-1$, Fishing mortality $(F)=$ $5.05 \mathrm{yr}-1$ and Exploitation rate $(E)=0.81$. Significant correlation $(r=0.9140-0.9770$ and $r=0.976-$ $0.977) .(P<Z 0.05)$ was observed between mesh sizes of gillnets and mean values of the morphometric characteristics (such as half-circumference, total length and total weight) of the fish. There is low percentage frequency range of the number of fish caught in different mesh sizes, possibly with low hanging coefficient range (0.4-0.5). Gilling, snagging, wedging, entangling were observed in the selection of the fishes. In conclusion, selectivity in Chrysichthys nigrodigitatus gillnet fishery in the Cross River estuary may be moderately adequate despite the influence of several other factors. The selection distribution curve using $17.5 \mathrm{~cm}$ estimated modal total length recommends the usage of $50 \mathrm{~mm}$ mesh size and above for exploitation of the species.
\end{abstract}

Keywords: Gillnet, Selectivity, Mortality, Length, Population

\section{Introduction}

In the Cross River estuary, Chrysichthys nigrodigitatus constitutes $66 \%$ by weight and $81 \%$ by number in the landings of the artisanal fishery, (Moses, 1987), confirming their dominant position as the target species are fished all the year round but with peak catches during the rainy months from May to October, which constitutes the main fishing season (Moses, 1987). Spawning and recruitment of the species also takes place all year round but with seasonal pulses. The major spawning peak occurs between July and September, and a secondary peak in January, while recruitment peak occur in May and December (Moses, 1987).

In describing the population dynamics of an exploited aquatic resource, a fundamental concept is that of stock. The stock is a group of organisms of one species having the same stock parameters and is victim of mortality and physiological features. Population dynamics is very important aspect of fisheries which becomes a welcome tool for management and conservatory measures (Begon et al., 1990). One essential feature of a stock is that the population parameters remain constant over the distribution area of the stock, so the stock parameters are operationally convenient in assessing the population dynamics of a given species (Mosepele, 2000). The primary objective of population dynamics is to provide advice on the optimum exploitation of aquatic living resources such as fish and shrimps. Since these resources are limited but renewable, a fish stock assessment may be obtained as a search for the exploitation level, which in the long run gives the maximum yield (Hovgard et al., 1999). The stocks targeted for this study which is Chrysichthys nigrodigitatus is commercial specie which is easily acceptable in the diet table of Nigerians. The result is that different fishing gears have been used in their exploitation, which result in non-fishable sizes seen in our Nigerian markets (Moses, 1987).

Gillnet fishing technique which is the most selective method of fishing worldwide and incidentally one of the most popular fishing techniques other than cast-netting in the study area is investigated. The selective capability of gillnets is afforded by the "mesh" which is the functional unit of the net. Different sizes of mesh determine different sizes of fish to be caught. Therefore, selectivity of gillnet can best be defined as the ability of the net to select different sizes of fish in

\footnotetext{
${ }^{1}$ Department of Biological Sciences, Cross River University of Technology, Calabar, Nigeria

${ }^{2}$ Department of Zoology and Environmental Biology, University of Calabar, Nigeria

${ }^{3}$ Department of Fisheries and Aquaculture, University of Uyo, Nigeria

*Corresponding author email: drecuttah@yahoo.com
} 
preference to others (Helser et al., 1991). The introduction of fine synthetic fishes such as nylon in the construction of fishing gear marked expansion in the commercial use of gillnets. The materials were cheaper and easier to handle, lasted longer and required less maintenance than natural fibres. Fibres such as nylon monofilaments become almost invisible in water, so nets made with synthetic twines generally caught greater numbers of fish than natural fibre nets used in comparable situations (Appelberg, 2000). Nylon is highly resistant to abrasion; hence the netting has the potential to last for many years if it is not recovered (Moses, 1988). Gillnet is a clear water fishery. In too deep water, the hydrostatic pressure can compress the usual floats of cork or plastic to such an extent that they lose their buoyancy and the gear can no longer function. With suitable floats, gillnets can be operated at a depth of $150 \mathrm{~m}$ and more (Brandt, 1972).

The consumption of animal protein enhances health, (FAO, 1981). Over $40 \%$ of the animal protein consumed in Nigeria comes from fish and contributes over $35 \%$ to the total quantity of fish available for consumption in the country (Olawuyi, 1992). Regulating and selecting the sizes of target fish is of primary concern in the conservation of the stock. The exploitation of Chrysichthys nigrodigitatus is an important fishery in the Cross River System. Chrysichthys nigrodigitatus is more abundant in the East and south-South Nigeria where the bottom deposits consists of soft and hard substrate. This work was aimed at ascertaining the population dynamics and gillnets selectivity of Chrysichthys nigrodigitatus in lower reaches of the Cross River estuary, Nigeria.

\section{Study area}

The study area in South-South Nigeria is defined here is the coastal zone lying between the Cross River at the Cameroun border (approximately longitudes 70 5 " $-80^{\circ} 35^{\prime \prime} \mathrm{E}$ and latitudes $3^{\circ} 45^{\prime \prime}-5^{\circ} 30^{\prime \prime} \mathrm{N}$ ) and encompassing Akwa Ibom, a fraction of the Rivers State East of the Niger Delta (Figure 1).

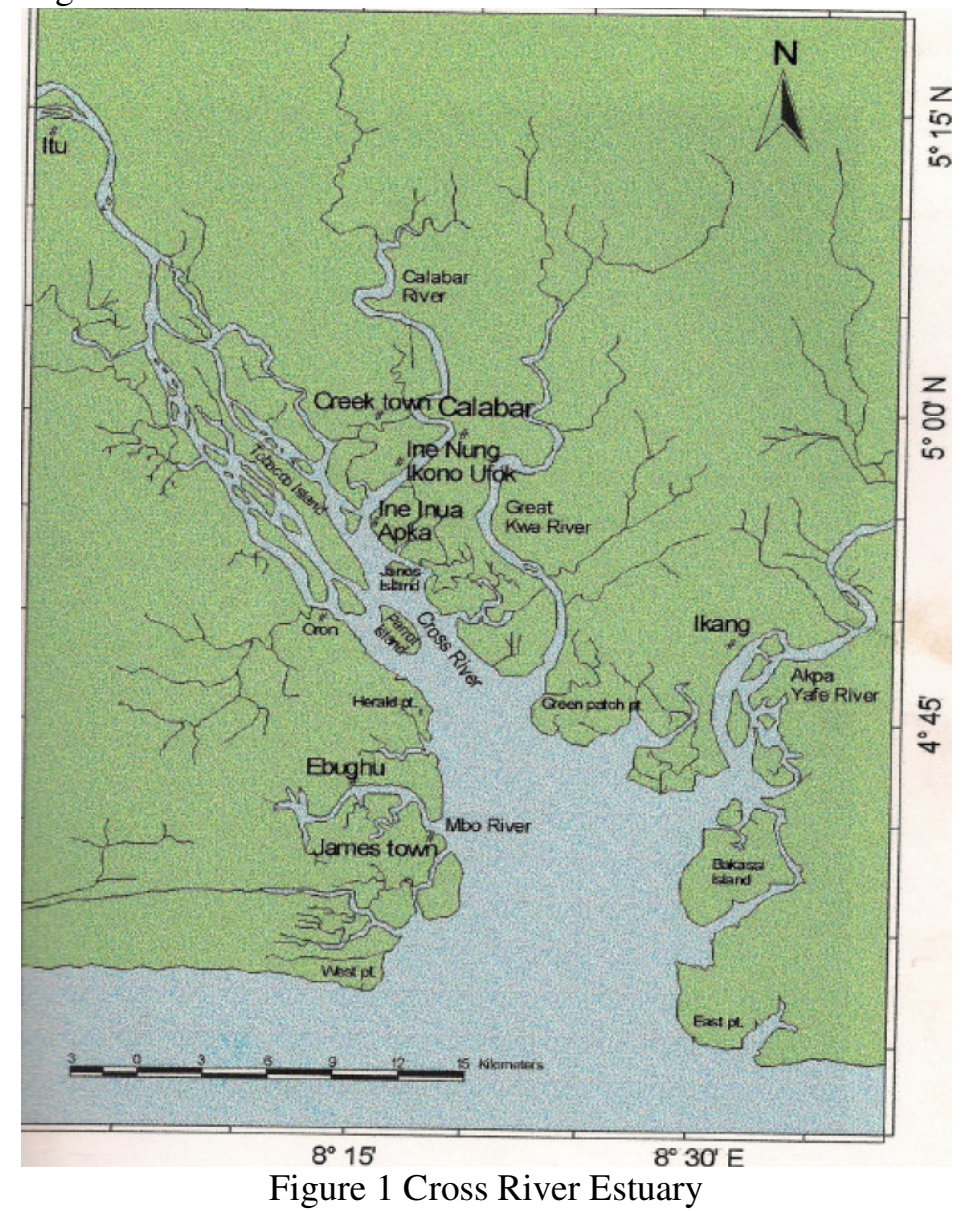


Fishing is always an important occupation of the people of South-South Nigeria. The climate of the study area is divided into a distinct wet season (April - October, with rainfall of $211-431 \mathrm{~mm}$ per month) and dry season (November - March, with rainfall of $32-156 \mathrm{~mm}$ per month); $55 \%$ of the annual precipitation occurs between June and September (Moses, 1990).

\section{Materials and Methods Samples Collection}

Sampling stations were selected at Mbo River, Itu beach and Calabar beach. Samples were collected bi-monthly. They were sorted into size categories. Each sample was obtained from total catch of known weight by mesh size. Samples were measured; length and weight measurements. Samples from all different mesh sizes were weighed for each gillnet and then pooled to lengthfrequency analysis. Different gillnets with different mesh sizes were used $-30 \mathrm{~mm}, 40 \mathrm{~mm}$, $50 \mathrm{~mm}, 60 \mathrm{~mm}, 70 \mathrm{~mm}, 80 \mathrm{~mm}, 100 \mathrm{~mm}$. the length measurement were taken according to conventional method, that is, "nearest unit below" to $0.1 \mathrm{~mm}$ precision for total length using a ruler. Girth was measured by using a simple tape measure or a string that is inelastic but calibrated.

The nets are set and checked at interval of 3-6 hours during day time but usually anchored and set in the evening and checked at dawn. Mesh size of the net which was measured as the distance between two opposite knots of a mesh when fully, stretched in a normal direction (Allcom, 1999).

Hanging coefficient (E) or ratios of the gillnet type (monofilament or multifilament) were obtained according to FAO (1978) as the ratio of length of the stapling rope to the number of meshes and mesh size hang on it. Frequency of occurrence, total length $(\mathrm{TL} \mathrm{cm})$, weight $(\mathrm{kg})$ and the girth or circumference $\left(\mathrm{O}^{\mathrm{ce}}\right)$ of the head around the operculum was obtained. The girth of individual fish caught by different mesh sizes were obtained with the aid of a flexible thin rope $(0=0.01 \mathrm{~m})$ tied around the head - operculuon or deepest part of the body and recorded in millimeters ( $\mathrm{mm}$ ).

\section{Data analysis}

A software package, FAO/ICLARM Stock assessment tools (FiSAT) (Pauly 1983) was used for length-frequency analysis. This composition incorporated ELEFAN O routine for data entry; ELEFAN I routine for estimating the growth curvature parameter $(\mathrm{K})$. Also incorporated in ELEFAN I is the routine for plotting the lengthconverted catch curves for estimating total mortality (Z). ELEFAN II programme of this FiSAT package is used to obtain recruitment pattern within a year, while ELEFAN III programme performs virtual population analysis (VPA).

ELEFAN I routine allows the estimation of von Bertalanffy growth parameter without knowing the age of the individuals was used to obtain $\mathrm{L}^{\infty}$ and $\mathrm{K}$. Von Bertallanffy growth equation below was used:

$$
\begin{aligned}
& \mathrm{L}_{\mathrm{t}}=\mathrm{L} \infty\left(1-\mathrm{e}^{-\mathrm{k}(\mathrm{t}-\mathrm{to})+(\mathrm{ck} / 2 \mathrm{x}) \sin (2 \mathrm{x}(\mathrm{t}-\mathrm{ts})}\right) \\
& \text { Where } \mathrm{L}_{\mathrm{t}}=\text { mean length at age } \mathrm{t} \text {. } \\
& \text { L } \infty=\text { asymptotic length } \\
& \mathrm{k}=\text { growth constant } \\
& \mathrm{t}_{\mathrm{o}}=\text { age at zero length } \\
& c=\text { constant expressing amplitude of } \\
& \text { seasonal oscillations in growth } \\
& \mathrm{t}_{\mathrm{s}}=\text { phase of oscillations. }
\end{aligned}
$$

Pauly (1984a) demonstrated that in nature, the oldest fish of a stock grow to about $95 \%$ of the asymptotic length. $L_{\infty} \approx \operatorname{Lmax} / 0.95$. Where Lmax is the maximum length observed in sample from the population. However, the longetivity of fishes were estimated from the relationship by Pauly (1980c) tmax $\approx 3 /$ IL. Instantaneous rate of total mortality (Z) was calculated from length converted catch curve analysis method incorporated in FiSAT package with the option accounting for seasonal growth (Gayanilo and Pauly, 1997). Using Pauly's empirical formula (Pauly 1980b) natural mortality $(\mathrm{M})$ was calculated with aid of length frequency data obtained. Upon the estimation of $\mathrm{Z}$ and $\mathrm{M}$, the $\mathrm{F}$-values were computed from the relationship $\mathrm{F}=\mathrm{Z}-\mathrm{M}$. And exploitation $(\mathrm{E})=\mathrm{E}=\mathrm{F} / \mathrm{z}$. Mean half Circumference $\left(1 / 20^{\text {ce }}\right)$. This was adopted in assumption that half the measured length of the circumference of the fish could approximate the mesh size (stretched) of the gillnet that length it (Erzini and Castro, 1998). Calculation was based on the mean, of the smallest and largest circumference range obtained from the fish caught by a particular mesh size. Circumference of fish girth measured could be assumed to be equal to the circumference of given mesh when cut and fully stretched. $\left(0^{\text {ce }}\right) \mathrm{F}=\left(0^{\text {ce }}\right)$ M. F and $\mathrm{M}$ represents fish and mesh respectively. Mean total weight was obtained by finding the average (i.e. 
dividing total weight of catches by total number of fish caught in a particular mesh size). Length frequency data obtained from catches of various mesh sizes were grouped according to length ranges of $2 \mathrm{~cm}$ intervals of their total length (TL). A selection distribution curve was obtained by plotting mesh size against percentage retention of the fish.

\section{Results}

Total length measurements of 7,852 specimens of Chrysichthys nigrodigitatus used are shown in Table 1 and Table 2. Seeding the preliminary values into ELEFAN I, a seasonalized growth curve was obtained with the following parameters $\mathrm{L} \infty=98.25 \mathrm{~cm}, \mathrm{~K}=0.96 \mathrm{yr}^{-1}$ amplitude of oscillation $(C)=0.15$, winter point $(\mathrm{WP})=0.15$, growth performance index $(\varphi)=3.08$ fig. $1 . \mathrm{Z}=$ $6.27 \mathrm{yr}^{-1}$ and $\mathrm{M}=1.22 \mathrm{yr}^{-1}$.

Yield per Recruit and Biomass per Recruit.
The Length at first Capture (Lc) L0.50 $=46.53 \mathrm{~cm}$ $\mathrm{L}=40.54 \mathrm{~cm}$ and $\mathrm{L} 0.75=50.19 \mathrm{~cm}$. Confidence Limit (CI) range of -1.33 to 12.88 gave a relative age of approximately. The knife-edge selection procedure (Figure 2) assumes that $\underline{C}$. nigrodigitatus smaller than LC $(46.53 \mathrm{~cm})$ is not captured by gear (Figure 3). The selection Ogive approach assumes that the probability of capturing any fish is proportional to its length. The knifeedge procedure gave the following results:

Emax $=0.661$, E0.1 $=0.568$, E0.5 $=0.358$ plot of exploitation rate $(\mathrm{E})$ against Relative yield/Recruit (Y/R) and Relative Biomass/Recruit (B/R) (Figure 4) indicated that increased exploitation rate $(\mathrm{E})$ resulted in increased yield/Recruit and subsequent decrease in Biomass/Recruit. The specie exhibits two recruitment pulses in a year, peaks of unequal magnitude (Figure 5). A selection distribution curve of percentage retention and the mesh sizes is normally distributed and peaked at $60 \mathrm{~mm}$ mesh size (Figure 6).

Plot - - -

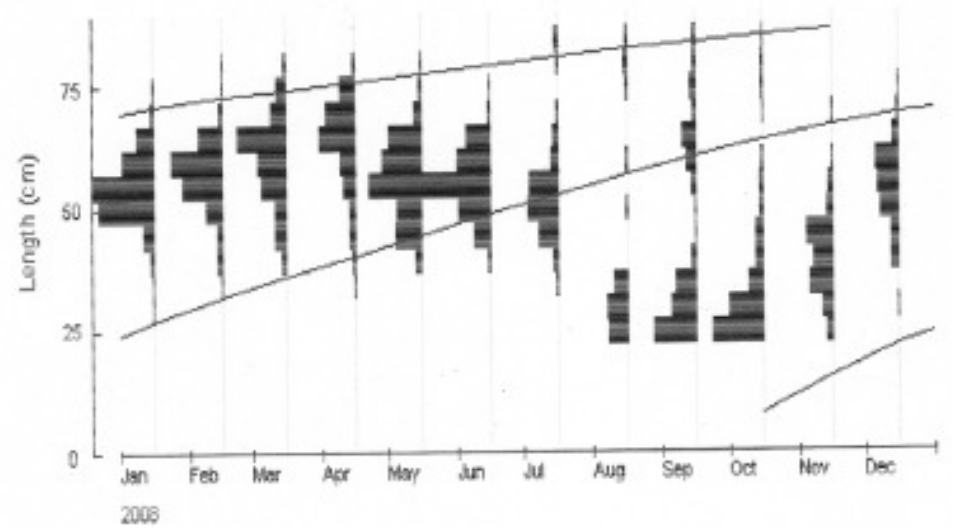

Figure 2 Growth curve of $C$. nigrodigitatus of the cross river reaches (L $\infty=98.25 \mathrm{~cm}, \mathrm{k}=0.96 \mathrm{year}-1, \mathrm{C}=0.15$, $\mathrm{wp}=0.15, \mathrm{rn}=0.205)$ superimposed on length-frequency data restructined by ELEFAN 1 programme.

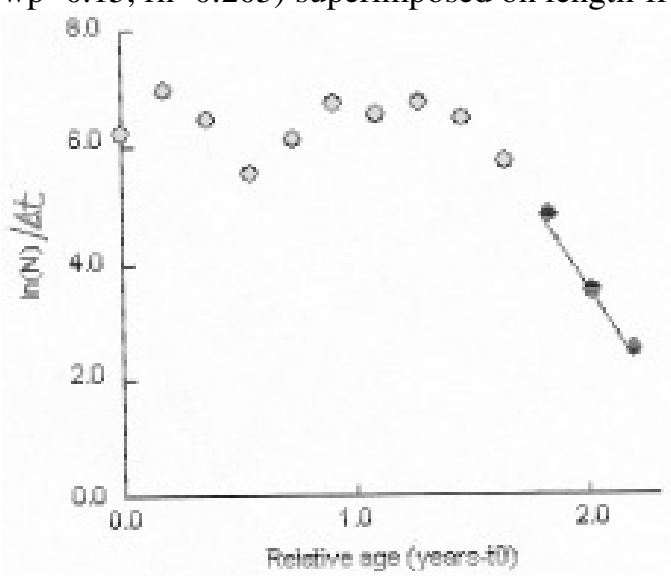

Figure 3 Length-converted catch curve of C.nigrodigitatus of the Cross River Reaches. Estimated z=6.27year -1 . 


\begin{tabular}{ccc|ccr}
$E$ & Y/R & B/R & E & Y/R & B/R \\
0.01 & 0.017 & 0.848 & 0.60 & 0.062 & 0.237 \\
0.20 & 0.031 & 0.704 & 0.70 & 0.063 & 0.153 \\
0.30 & 0.043 & 0.570 & 0.80 & 0.060 & 0.085 \\
0.40 & 0.052 & 0.447 & 0.80 & 0.054 & 0.034 \\
0.50 & 0.058 & 0.335 & 0.99 & 0.048 & 0.003
\end{tabular}

Plot

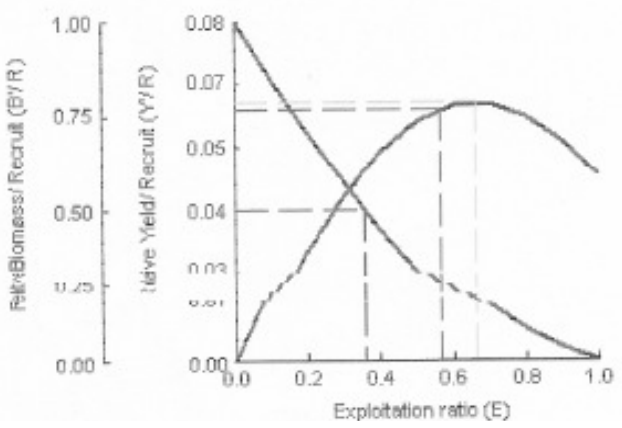

Figure 4 Related yield/Recruit Analysis (knifeedge) of C. nigrodigitatus of the Cross River Reaches. E0.1 $=0.568, \mathrm{E} 0.5=0.358$ Emaxa $=0.661$.

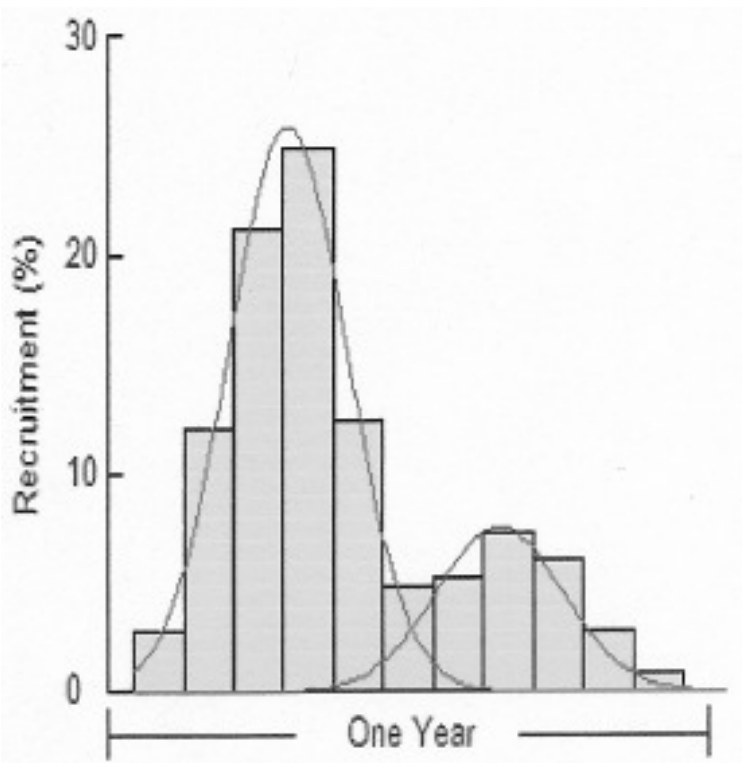

Figure 6 Recruitment pattern of $C$. nigrodigitatus of the Cross River Reaches, indicating two peaks of unequal magnitude within an arbitrary year.

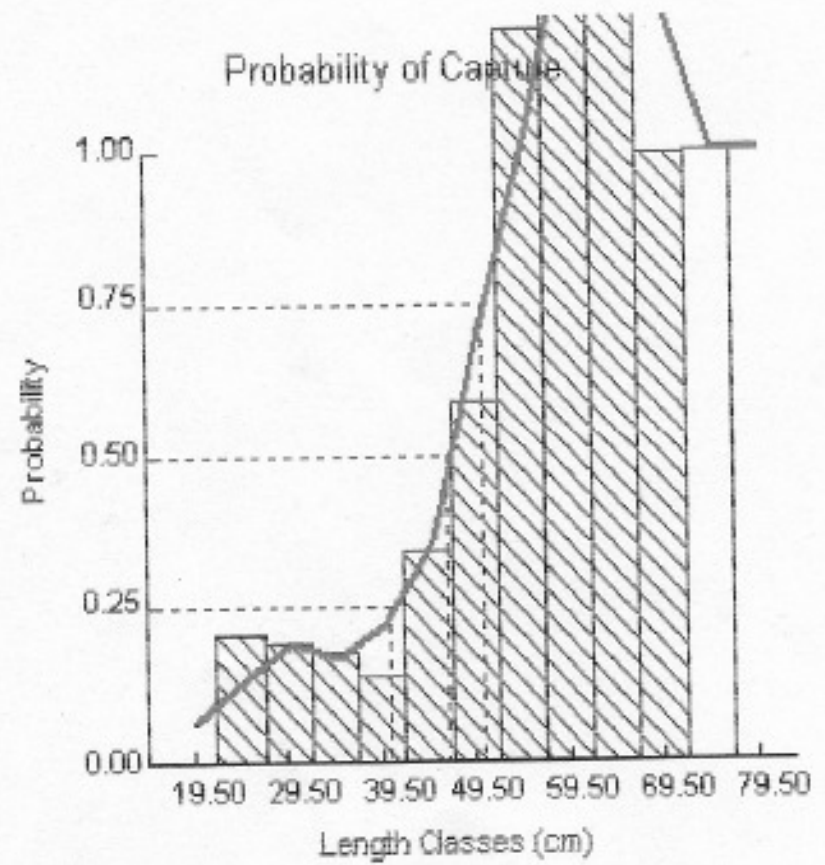

Figure 5 Probability of capture of $C$. nigrodigitatus as estimated from the ascending arm of the catch curve. The length at first capture $(46.53 \mathrm{~cm})$. 
Table 1 Total length (TL) frequency data of Chrysichthys nigrodigitatus taken from the reaches of the Cross River, Nigeria from January to December, 2008. ML = Mid

Length of class interval.

\begin{tabular}{|c|c|c|c|c|c|c|c|c|c|c|c|c|c|}
\hline ML/Date & 01/8 Jan & $\begin{array}{l}02 / 08 \\
\text { Feb }\end{array}$ & $\begin{array}{l}03 / 08 \\
\text { Mar }\end{array}$ & $\begin{array}{l}04 / 08 \\
\text { April }\end{array}$ & $\begin{array}{l}\text { 05/08 } \\
\text { May }\end{array}$ & $\begin{array}{l}06 / 08 \\
\text { June }\end{array}$ & $\begin{array}{l}07 / 08 \\
\text { July }\end{array}$ & $\begin{array}{l}08 / 08 \\
\text { Aug }\end{array}$ & $\begin{array}{l}\text { 09/08 } \\
\text { Sept. }\end{array}$ & $\begin{array}{l}10 / 08 \\
\text { Oct }\end{array}$ & $\begin{array}{l}11 / 08 \\
\text { Nov }\end{array}$ & $\begin{array}{l}12 / 08 \\
\text { Dec }\end{array}$ & \\
\hline 24.5 & - & - & - & - & - & - & - & 90 & 217 & 263 & 23 & - & \\
\hline 29.5 & 1 & - & - & - & - & - & - & 102 & 128 & 172 & 46 & 3 & \\
\hline 34.5 & 1 & 3 & - & 2 & - & - & 7 & 61 & 103 & 70 & 114 & - & \\
\hline 39.5 & 8 & 27 & 12 & 8 & 27 & 8 & 18 & 0 & 16 & 32 & 92 & 33 & \\
\hline 44.5 & 50 & 24 & 50 & 19 & 131 & 84 & 93 & 0 & 5 & 28 & 125 & 39 & \\
\hline 49.5 & 277 & 82 & 51 & 23 & 126 & 163 & 154 & 8 & 1 & 14 & 26 & 93 & \\
\hline 54.5 & 322 & 203 & 122 & 59 & 266 & 390 & 141 & - & 22 & 16 & 14 & 111 & \\
\hline 59.5 & 153 & 263 & 137 & 71 & 197 & 173 & 33 & 1 & 41 & 6 & 1 & 118 & \\
\hline 64.5 & 80 & 124 & 243 & 179 & 166 & 124 & 22 & - & 68 & 0 & 0 & 29 & \\
\hline 69.5 & 11 & 15 & 70 & 143 & 34 & 13 & 3 & - & 15 & 3 & 1 & 12 & \\
\hline 74.5 & 3 & 5 & 38 & 74 & 11 & 1 & 0 & 7 & 27 & 9 & - & 1 & \\
\hline 79.5 & - & 1 & 6 & 5 & 2 & - & 9 & 16 & 13 & 5 & - & - & \\
\hline 84.5 & - & - & - & - & - & - & 12 & 8 & 11 & 1 & - & - & \\
\hline \multirow[t]{2}{*}{89.5} & - & - & - & - & - & - & 1 & 8 & 4 & 6 & - & - & \\
\hline & 906 & 747 & 729 & 583 & 960 & 956 & 493 & 301 & 671 & 625 & 442 & 439 & $=7,852$ \\
\hline
\end{tabular}


Table 2: $\quad$ Length frequencies, weight and mean half circumference of girth of Chrysichthys nigrodigitatus caught in gill nets of various mesh sizes in the study area

\begin{tabular}{|c|c|c|c|c|c|c|c|c|c|c|c|c|c|c|c|c|c|c|c|}
\hline \multirow{3}{*}{$\begin{array}{l}\text { Mean } \\
\text { Weight } \\
\text { (g) }\end{array}$} & \multirow{3}{*}{$\begin{array}{l}\text { Mean } \\
1 / 2 \text { Ōce } \\
(\mathrm{mm})\end{array}$} & \multirow{3}{*}{$\begin{array}{c}\text { Mean } \\
\text { Total } \\
\text { Length } \\
(\mathrm{mm})\end{array}$} & \multicolumn{14}{|c|}{ MESH SIZES OF GILL NETS } & \multirow{3}{*}{$\begin{array}{c}\text { Log } \\
\text { Mean } \\
\text { Weight } \\
(\mathrm{g})\end{array}$} & \multirow{3}{*}{$\begin{array}{l}\text { Log } \\
\text { Mean } \\
1 / 2 \text { Ōce } \\
(\mathrm{mm})\end{array}$} & \multirow{3}{*}{$\begin{array}{c}\text { Log } \\
\text { Mean } \\
\text { Total } \\
\text { Length } \\
(\mathrm{mm})\end{array}$} \\
\hline & & & \multirow{2}{*}{$\begin{array}{l}30 \\
\text { Freq } \\
\text { (n) }\end{array}$} & \multirow{2}{*}{\multicolumn{2}{|c|}{$\begin{array}{l}40 \\
\text { req } \\
\text { n) }\end{array}$}} & \multirow[b]{2}{*}{$\begin{array}{c}\% \\
\text { Freq. }\end{array}$} & \multirow{2}{*}{$\begin{array}{l}50 \\
\text { Freq } \\
(\mathrm{n})\end{array}$} & \multirow{2}{*}{\multicolumn{2}{|c|}{$\begin{array}{l}\quad 60 \\
\text { Freq } \\
(n)\end{array}$}} & \multirow{2}{*}{\multicolumn{2}{|c|}{$\begin{array}{l}70 \\
\text { req } \\
\text { (n) }\end{array}$}} & \multirow[b]{2}{*}{$\begin{array}{c}\% \\
\text { Freq. }\end{array}$} & \multirow{2}{*}{$\begin{array}{l}80 \\
\text { Freq } \\
(\mathrm{n})\end{array}$} & \multirow{2}{*}{\multicolumn{2}{|c|}{$\begin{array}{l}100 \\
\text { Freq } \\
(\mathrm{n})\end{array}$}} & \multirow[b]{2}{*}{$\begin{array}{c}\% \\
\text { Freq. }\end{array}$} & & & \\
\hline & & & & & & & & & & & & & & & & & & & \\
\hline 14.4 & 22.4 & 110 & 124 & 12.1 & & & & & & & & & & & & & 1.16 & 1.35 & 2.04 \\
\hline 15.6 & 24 & 130 & 188 & 18.4 & 62 & 7.1 & & & & & & & & & & & 1.19 & 1.38 & 2.11 \\
\hline 26.3 & 29.3 & 150 & 180 & 17.6 & 76 & 8.7 & & & & & & & & & & & 1.42 & 1.47 & 2.18 \\
\hline 39.4 & 32.3 & 170 & 258 & 25.3 & 84 & 9.6 & 32 & 5.8 & & & & & & & & & 1.60 & 1.51 & 2.23 \\
\hline 55.3 & 38.6 & 190 & 172 & 16.8 & 102 & 11.6 & 35 & 6.4 & 20 & 3.9 & & & & & & & 1.74 & 1.59 & 2.28 \\
\hline 70.1 & 42.6 & 210 & 90 & 8.8 & 130 & 14.8 & 62 & 11.3 & 26 & 5.1 & & & & & & & 1.85 & 1.63 & 2.32 \\
\hline 94.3 & 46.5 & 230 & 0 & 0.0 & 238 & 27.1 & 84 & 15.3 & 34 & 6.7 & & & & & & & 1.97 & 1.67 & 2.36 \\
\hline 180.6 & 55.3 & 250 & 0 & 0.0 & 82 & 9.3 & 112 & 20.4 & 38 & 7.5 & 17 & 2.9 & & & & & 2.26 & 1.74 & 2.40 \\
\hline 186.4 & 60.3 & 270 & 0 & 0.0 & 52 & 5.9 & 78 & 14.2 & 70 & 13.8 & 34 & 5.7 & & & & & 2.27 & 1.78 & 2.43 \\
\hline 203 & 65.3 & 290 & 0 & 0.0 & 30 & 3.4 & 42 & 7.6 & 160 & 31.6 & 42 & 7.1 & & & & & 2.31 & 1.81 & 2.46 \\
\hline 205 & 68.6 & 310 & 5 & 0.5 & 14 & 1.6 & 30 & 5.5 & 62 & 12.2 & 66 & 11.1 & & & & & 2.31 & 1.84 & 2.49 \\
\hline 210 & 75 & 330 & 3 & 0.3 & 6 & 0.7 & 24 & 4.4 & 38 & 7.5 & 86 & 14.5 & 6 & 2.2 & & & 2.32 & 1.88 & 2.52 \\
\hline 253 & 68.6 & 350 & 0 & 0.0 & 0 & 0.0 & 20 & 3.6 & 22 & 4.3 & 142 & 23.9 & 12 & 4.4 & & & 2.40 & 1.84 & 2.54 \\
\hline 301 & 75.7 & 370 & 0 & 0.0 & 0 & 0.0 & 16 & 2.9 & 18 & 3.6 & 73 & 12.3 & 34 & 12.5 & & & 2.48 & 1.88 & 2.57 \\
\hline 302 & 74 & 390 & 0 & 0.0 & 0 & 0.0 & 10 & 1.8 & 9 & 1.8 & 40 & 6.7 & 48 & 17.6 & & & 2.48 & 1.87 & 2.59 \\
\hline 342 & 77.9 & 410 & 0 & 0.0 & 0 & 0.0 & 4 & 0.7 & 6 & 1.2 & 30 & 5.1 & 58 & 21.3 & & & 2.53 & 1.89 & 2.61 \\
\hline 352 & 80 & 430 & 1 & 0.1 & 0 & 0.0 & & & 2 & 0.4 & 22 & 3.7 & 64 & 23.5 & 38 & 18.1 & 2.55 & 1.90 & 2.63 \\
\hline 610 & 95.6 & 450 & & & 2 & 0.2 & & & 1 & 0.2 & 14 & 2.4 & 18 & 6.6 & 43 & 20.5 & 2.79 & 1.98 & 2.65 \\
\hline 675 & 103.6 & 470 & & & & & 1 & 0.2 & 0 & 0.0 & 14 & 2.4 & 18 & 6.6 & 56 & 26.7 & 2.83 & 2.02 & 2.67 \\
\hline 750 & 106.9 & 490 & & & & & & & 1 & 0.2 & 14 & 2.4 & 14 & 5.1 & 73 & 34.8 & 2.88 & 2.03 & 2.69 \\
\hline \multicolumn{3}{|c|}{ Total number of fish } & 1021 & 100 & 878 & 100 & 550 & 100 & 507 & 100 & 594 & 100 & 272 & 100 & 210 & 100 & & & \\
\hline \multicolumn{3}{|c|}{ Total weight (kg) } & \multicolumn{2}{|c|}{14.72} & \multicolumn{2}{|c|}{24.22} & \multicolumn{2}{|c|}{29.32} & \multicolumn{2}{|c|}{35.2} & \multicolumn{2}{|c|}{40.11} & \multicolumn{2}{|c|}{39.2} & \multicolumn{2}{|c|}{30.51} & & & \\
\hline Mean tot & al length & $(\mathbf{m m})$ & 1 & & & & & & 20 & & & 1 & 31 & & & & & & \\
\hline Range of & 1/20̈ce (n & am) & 29 & & & & & & 68 & & & .7 & 9 & & & 5.9 & & & \\
\hline
\end{tabular}


Population Dynamics and Gillnets Selectivity of Chrysichthys nigrodigitatus......................jang et al.

\section{Discussion}

The growth curves estimated indicates a seasonal growth, and that growth drastically slows down in certain period of the year $\mathrm{C}=0.15$ in Chrysichthys nigrodigitatus. Winter point (WP) of 0.15 implies that the poorest growth occurs in July. The month of February and March are about the warmest in the year, with surface temperatures generally above $30^{\circ} \mathrm{C}$. Hovard et al., (1999) noted that in temperate waters feeding often slow down or ceases in the summer, when temperatures reaches $29^{\circ} \mathrm{C}$ or higher. This will affect the gillnet selectivity as it becomes difficult for a reasonable catch to be observed. The twine diameter increased especially monofilament nets. Gillnet of $30 \mathrm{~mm}$ is best used during this period as increase in twine diameter will not be too large.

The poorest growth in July may be associated with their reproductive activities in the period. They spawn in the estuary but this comes to a peak in July to September (Offem, et al., 2008). The poor growth in this month of July had earlier been noted by Atobatele and Ugwumba (2011). The estimated value of the growth coefficient $(\mathrm{K})$ of $0.96 \mathrm{yr}^{-1}$ fall within the estimated value for Cynodrontis spp stocks by Pauly et al. (1984). The $\mathrm{L} \infty$ estimation of $98.25 \mathrm{~cm}$ is compared with maximum length of $120 \mathrm{~cm}$ observed for species in the Lagos lagoon (Mairoghae, 1982). The presence of two recruitment peaks per year is in accordance with earlier results on prawns in tropical regions (Pauly et al., 1984), and confirms the assertion of Pauly (1980b), and Dwiponggo et al. (1986) that the two recruitment pulses per year may be typical of tropical fish and invertebrate stocks.

Instantaneous rate of total mortality (Z) of $6.27 \mathrm{yr}^{-1}$ and exploitation rate of 0.81 , shows there is fishing pressure on Chrysichthys nigrodigitatus. This is based on the assumption of Gulland (1971) that in an optimally exploited stocks, the natural and the fishing mortalities should be equal i.e. $\mathrm{E}=$ $\mathrm{F} / \mathrm{Z}=0.5$. Comparing this result with the relative yield-per-recruit analysis would seem to confirm this assertion that the Chrysichthys nigrodigitatus populations are over fished with gillnet of mesh sizes of $30 \mathrm{~mm}$ and $40 \mathrm{~mm}$.

The monofilament surface driftnets are preferred because of their reduced visibility in water (Brandt, 1972). Morphometric relationship of the catches in different mesh sizes of the gillnet shows a significant correlation range $(r=0.9140-0.9970)$, indicating fish size (circumference, total length and weight) selected by the gear depended on the mesh sizes of the net used. This is in line with the work of Udolisa et al. (1979) in the Cross River Nigeria. The ratio of $1.4 / 2.5$ circumference by weight obtained from the log-log transformations of total length with circumference and weight signify a higher increase rate in weight than circumference per unit increase in length. While circumference increases, this being one of the factors that control selectivity by gilling and enmeshment weight increase attains an allometirc rate (2.5). The value 2.5 obtained from computation falls within the limits of 2.0-3.5 range (Beverton and Bolts, 1957; 2.5-3.5 range. Carlender, 1969; 2.5-4.0 range. Lagter et al., 1997) which shows that no fish actually grow isometrically due to differences in the condition factor of the fish. However, growth of fish is isometric at the early age (to) and allometric at later age $(\max )(B e g e n a l$ and Tesch, 1979). The low hanging coefficient of gillnet result in entangling of a wider size range of the species by a particular mesh size. Aside gilling, some were wedge (caught at the targets body depth) and snagged. Shape and behaviour of the fish could be contributive factors that moderate selectivity of the net (Anyanwu, 1991). Others include net construction and visibility of the net in water (Brazil and Wolters, 2002).

The selection distribution curve obtained from the estimated modal total length of a $98.25 \mathrm{~cm}$ is the combined effect of gilling, wedging, snagging and entangling which did not deviate from the normal dumbbell shape curve of gillnet selectivity. This means gilling which is the catching patterns that dominate all others in effect of mesh size alone. Selectivity in Chrysichthys nigrodigitatus gillnet fishery in the Cross River estuary may be moderately adequate despite the influence of several other factors. There are selectivity deviations in some gillnet fishery. Mohanty (2004), noted such deviation in the exploitation of Chrysichthys nigrodigitatus in lower Cross River, Nigeria.

\section{References}

Allcom, R. I. (1999). The East Caprivi floodplain fishery. An assessment of the health and value of a local level resource.M. scient.Thesis, University of Cape Town, South Africa, 53 pp. 
Anyanwu, P. E. 1991. Influence of salinity on survival of fingerlings of the estuarine catfish Chrysichthys nigrodigitatus (Lacépède). Aquaculture, 99:157-165..

Appelberg, M. (2000). Swedish standard methods for sampling fresh water fish with multi-mesh gillnets. Fiskerivecket information, 1,32pp

Atobatele, O. E. and Ugwumba, A. O. (2011). Condition factor and diet of Chrysichthys nigrodigitatus and Chrysichthys auratus (Siluriformes: Bagridae) from Aiba Reservoir, Iwo, Nigeria. Revista de Biología Tropical, 59 (3): 1233-1244.

Begon, M., Harper, J. L., and Townsend, C. R. (1990). Ecology: Individuals, population and communities. $2^{\text {nd }}$ ed. Blackwell Scientific publication, 945pp

Beverton, R. J. H and Holt,S. J. (1957).On the Dynamics of Exploited Fish Populations.Fish Investment, Ministry of Agriculture, Fish Food. G.B. 2-Sea Fish, 19:533p.

Brandt, A.V.(1972). Fish Catching Methods of the World, Fishing News Ltd. $1^{\text {st }}$ Edition. $418 \mathrm{p}$

Brazil, B. L. and Wolters, W. R. (2002). Hatch success and fingerling growth of channel catfish cultured in ozonated hatchery water. North American Journal of Aquaculture,64: 144-149

Dwiponggo, A. T., Hariati, S., Banon, M. L. Palomares and Pauly,D. (1986).Growth mortality and recruitment of commercially important fishes and penacid shrimps in Indonesian waters. ICLARM Technical Reports 17, 91p

Erzini, K., and Castro, M. (1998). An alternative methodology for fitting selectivity curves to predefined distributions. Fisheries Research,34:307-313

FAO (1978). FAO Catalogue of Small-Scale Fishing gear designs, Famhan, Survey, Fishing news books.FAO, 159p.

FAO (1981). Methods of collecting and analyzing size and age data for fish stock assessment. FAO Fishery Circular,736: 100pp.

Gulland, J. A., (1971). The fish resources of the Ocean. West By Fleet, survey. Fishing News Books Ltd, FAO. 255 p.

Helser, T. E., Geaghan, J., and Condrey, R. E. (1991).A new method for estimating gillnet selectivity, with an example for spotted seatrout, Cynosion nebulosus. Canadian. Journal of fishery. Aquatic science.,48:487-492.
Hovgard, H., Lassen, H., Madson, N., Poulsen, T. M. and Wileman, D. (1999). Gillnet selectivity for North Sea cod (Gardus morhuиa): model ambiguity and data quality are related. Can J. Fish. Aquat. Sci.,56: 1307-1316

Mohanty, R. K. (2004). Density dependent growth, performance of Indian major carps in rain water reservoirs. Journal of applied ichthyology,20: 123-127

Mosepele, K. (2000). Preliminary length based stock assessment of the main exploited stocks of the Okavango Delta fishery. Mphil. Thesis. Department of Fisheries \& Marine Biology, University of Bergen, Norway. 139pp

Moses, B. S. (1987). The Influence of Flood Regime on Fish catch and Fish Communities of the Cross River Flood plain Ecosystem, Nigeria. Environmental Biology of Fishes, 18(1): 15-65.

Moses, B. S. (1988). Growth, mortality and potential yield of bonga, Ethmalosa finbriata (Bowdich, 1825) of Nigerian inshore waters.Fisheries Research, 6:233-247.

Moses, B. S. (1990). Growth, biomass, mortality, production and potential yield of the West African clam (Egeria radiate, E. lanmarck, E. lamellibranchia, E. donacidae) in the Cross River System, Nigeria. Hydrobiologia, 196:1-15.

Offem, B. O., Yemi, A. S., and Isaac, T. O. (2008). Diet size and reproductive biology of the silver catfish, Chrisichthys nigrodigitatus in the Cross River, Nigeria.Revista de Biologia Tropica. Olawuyi, E. I. O. (1992). Strategies for meeting the fishing input requirements of small-scale artisanal fisheries. Proceeding of the $10^{\text {th }}$ Annual conference of the fisheries society of Nigeria. A.A. Eyo \& A. M. Balogun (eds). Abeokula, November 16-20. pp. $185-190$.

Pauly, D. (1980b). On the interrelationships between natural mortality, growth parameters \& mean environmental temperature in 175 fish stocks. Journal du counseil 1 international pour I' Exploration de la mer, 39 (3):175 - 192.

Pauly D. (1980c). A selection of simple methods for the assessment of tropical Fish stocks. FAO Fisheries circular, 729: 54p.

Pauly, D. (1983). Some simple methods for the assessment of tropical stock. FAO Fish. Tech. Pap., (234): 52p.

Pauly, D. (1984). Length converted catch curves: Powerful tool for fisheries research in the tropics. Part 2. Fishbyte. 4: 17-19. 
Pauly, D. (1984). Fish population dynamics in tropical waters: a manual for programmable calculators. ICLARM Study Review. 8: 35 p.

Pauly, D., Ingles J. and Neal,R. (1984).Application to shrimps Stock of objective methods for the estimation of growth, mortality and recruitment - related parameters from lengthfrequency data (ELEFAN I \& II). Pp. 220 - 234. In: J. A. Guland \& B. J. Rothschild (eds.),
Penaeid shrimps their biology \& management. Fishing News Books, Farnham, survey, England. 308p.

Udolisa, R. E. K, Solarin, B. B., Lebo, P. E. and Ambrose, E. E. (1992).. A catalogue of Smallscale Fishing gear in Nigeria. FAO Regional Office for Africa. (RAFR) publication. RAFR/01/94/02.142p. 